\title{
Cocaine Decreases Metabotropic Glutamate Receptor mGluRI Currents in Dopamine Neurons by Activating mGluR5
}

\author{
Paul F Kramer' and John T Williams*,I \\ 'Vollum Institute, Oregon Health and Science University, Portland, OR, USA
}

\begin{abstract}
Midbrain dopamine neurons are important mediators of reward and movement and are sensitive to cocaine-induced plasticity. After even a single injection of cocaine, there is an increase in AMPA-dependent synaptic transmission. The present study examines cocaine-induced plasticity of mGluR-dependent currents in dopamine neurons in the substantia nigra. Activation of mGluRI and mGluR5 resulted in a mixture of inward and outward currents mediated by a nonselective cation conductance and a calcium-activated potassium conductance (SK), respectively. A single injection of cocaine decreased the current activated by mGluRI in dopamine neurons, and it had no effect on the size of the mGluR5-mediated current. When the injection of cocaine was preceded by treatment of the animals with a blocker of mGluR5 receptors (MPEP), cocaine no longer decreased the mGluRI current. Thus, the activation of mGluR5 was required for the cocaine-mediated suppression of mGluRI-mediated currents in dopamine neurons. The results support the hypothesis that mGluR5 coordinates a reduction in mGluRI functional activity after cocaine treatment.
\end{abstract}

Neuropsychopharmacology (2015) 40, 24I8-2424; doi:I0.1038/npp.2015.9I; published online 29 April 2015

\section{INTRODUCTION}

Group I metabotropic glutamate receptors (mGluR1 and mGluR5) are Gq-coupled receptors that modulate cocaineinduced plasticity (Bird et al, 2014; Yu et al, 2013). Although mGluR1 and mGluR5 signal through the same class of G proteins (Hermans and Challiss, 2001), selective activation of these receptors results in differing synaptic and behavioral outcomes induced by treatment of animals with cocaine. Increasing mGluR1 activity $24 \mathrm{~h}$ after a single injection of cocaine reversed the well-described potentiation of AMPA receptor EPSCs in the ventral tegmental area (VTA, Bellone and Luscher, 2006; Ungless et al, 2001). The underlying mechanism involved an mGluR1-dependent long-term depression that removed calcium-permeable AMPA receptors (Bellone and Luscher, 2005,2006). This observation raised the possibility that a decrease in basal mGluR1 signaling was necessary for cocaine-induced plasticity.

The role of mGluR5 in drug-induced plasticity is less well understood. Inhibition of mGluR5 by a variety of selective negative allosteric modulators or genetic knockout decreased cocaine self-administration (Kenny et al, 2005; Chiamulera, 2001), cue-induced reinstatement (Kumaresan et al, 2009), cocaine taking and seeking (Keck et al, 2013, 2014), and

*Correspondence: Dr JT Williams, Vollum Institute, Oregon Health and Science University, Vollum Institute L474, 318I SW Sam Jackson Park Road, Portland, OR 97239, USA, Tel: +503 494 5465, Fax: +503 494 4590, E-mail: williamj@ohsu.edu

Received I 9 February 2015; revised I 8 March 2015; accepted 25 March 2015; accepted article preview online I April 2015 extinction in rats and monkeys (Bird et al, 2014; Keck et al, 2013, 2014; Kumaresan et al, 2009; Platt et al, 2008). Thus, blocking mGluR5 activity decreased behaviors associated with cocaine treatment and self-administration, whereas blockade of mGluR1 facilitated cocaine-dependent processes on AMPA receptor-dependent EPSCs in the nucleus accumbens (Loweth et al, 2013). It remains unknown how cocaine treatment directly affects mGluRs on dopamine neurons.

The coexpression of mGluR1 and mGluR5 is found in a variety of areas, including pyramidal neurons, type II globus pallidus neurons, and dopamine neurons of the olfactory bulb (Jian et al, 2010; Mannaioni et al, 2001; Poisik et al, 2003). Dopamine neurons of the ventral midbrain also coexpress mGluR1 and mGluR5, as measured by immuno-gold EM and in situ hybridization studies (Hubert et al, 2001; Testa et al, 1994). Functionally, it is known that mGluR1 evokes calcium release from intracellular stores, which activate SK channels in midbrain dopamine neurons resulting in a pause of firing (Fiorillo and Williams, 1998; Morikawa et al, 2003). The role of mGluR5 in dopamine neurons is not known.

This study examines the mechanisms that link the activation of mGluR1 and mGluR5 to cocaine-induced neuronal plasticity in dopamine neurons. Initial experiments demonstrate that both receptors activate the same conductances. Following a single injection of cocaine, the mGluR1-dependent currents were significantly decreased, whereas mGluR5dependent currents were unchanged. Finally, pharmacological blockade of mGluR5 in vivo before injection of cocaine blocked the cocaine-induced decrease in mGluR1-dependent 
currents. Thus, activation of mGluR5 after cocaine coordinates the reduction in mGluR1.

\section{MATERIALS AND METHODS}

\section{Animals}

All animal experiments were performed in accordance with the National Institutes of Health guidelines and with approval from the Institutional Animal Care and Use Committee of the Oregon Health \& Science University (Portland, OR). Adult (5-10 weeks), male and female, wild-type C57 or C57/129 mice were used for all experiments. Mice were injected with cocaine $(20 \mathrm{mg} / \mathrm{kg})$ or saline intraperitoneally (i.p.) and immediately replaced into their home cage. Some experiments consisted of naïve animals grouped with salineinjected animals. There is no significant difference in the mGluR iontophoretic-induced current between these two conditions $(t(17)=1.4, p>0.05)$.

\section{Slices and Solutions}

Horizontal slices $(220-230 \mu \mathrm{m})$ containing the substantia nigra were prepared (as previously described in Gantz et al, 2013). Slices were cut using a vibratome (Leica) in an icecold physiological ACSF containing $126 \mathrm{mM} \mathrm{NaCl}, 2.5 \mathrm{mM}$ $\mathrm{KCl}, 1.2 \mathrm{mM} \mathrm{NaH} \mathrm{PO}_{4}, 1.2 \mathrm{mM} \mathrm{MgCl}_{2}, 2.4 \mathrm{mM} \mathrm{CaCl}$, $11 \mathrm{mM}$ glucose, $21.4 \mathrm{mM} \mathrm{NaHCO}_{3}$, and $5 \mathrm{mM} \mathrm{MK801,}$ saturated with $95 \% \mathrm{O}_{2}$ and $5 \% \mathrm{CO}_{2}, \mathrm{pH} 7.4,300 \mathrm{mOsm} / \mathrm{kg}$, and then incubated in the same solution warmed to $34{ }^{\circ} \mathrm{C}$ for at least $30 \mathrm{~min}$. Slices were placed in a recording chamber and superfused with warmed $\left(35^{\circ} \mathrm{C}\right)$ physiological ACSF at 1.5 to $2 \mathrm{ml} / \mathrm{min}$.

\section{Whole-Cell Recording}

All recordings were performed from dopamine neurons of the substantia nigra pars compacta, defined as a region lateral to the medial terminal nucleus of the accessory optic tract. Dopamine neurons were identified by their large cell bodies, the characteristic pacemaker-like firing $(1-5 \mathrm{~Hz})$ observed in the cell-attached mode, and the presence of a large Ih current. Whole-cell pipettes had resistances of 1.5-1.8 M $\Omega$. Unless otherwise stated, pipette solutions used for whole-cell recordings contained (in mM) $115 \mathrm{mM} \mathrm{K}$-methanesulfonate, $20 \mathrm{mM} \mathrm{NaCl}, 1.5 \mathrm{mM} \mathrm{MgCl}_{2}, 5 \mathrm{mM}$ HEPES, 0.1 mM EGTA, 2 mM Mg-ATP, $0.25 \mathrm{mM} \mathrm{Na}_{2}-\mathrm{GTP}$, and $10 \mathrm{mM}$ $\mathrm{Na}_{2}$ phosphocreatine, $\mathrm{pH} 7.38,282 \mathrm{mOsm} / \mathrm{kg}$. Voltage-clamp recordings were made (holding potential $-55 \mathrm{mV}$ ) using an Axopatch 200B amplifier (Axon Instruments, Foster City, $\mathrm{CA})$. Series resistance was monitored using a $2-\mathrm{mV}$ square test pulse (collected at $50 \mathrm{kHz}$ and filtered at $10 \mathrm{kHz}$ ). Recordings were discarded if the series resistance exceeded $10 \mathrm{M} \Omega$. Episodic data were obtained at $5 \mathrm{kHz}$ and filtered at 2 or $5 \mathrm{kHz}$ using AxoGraph $\mathrm{X}$ (Axon Instruments). Continuous recordings were obtained using Chart (version 5.5.6, AD Instruments, Colorado Springs, CO).

\section{mGluR-Mediated Currents}

The mGluR-dependent outward current desensitizes rapidly. Thus, rapid and short-lasting application of agonists was required to obtain a steady reproducible response. This was achieved either by iontophoresis of L-aspartate or local pressure ejection of DHPG $(100 \mu \mathrm{M})$. Iontophoresis was performed with an Axoclamp $2 \mathrm{~A}$ amplifier (Axon Instruments, -80-130 nA ejection current, +7-11 nA backing current) using pipettes containing aspartate (1 M, pH 7.4, 40-70 M $\Omega$ ). Iontophoretic pipettes were placed within $5-10 \mu \mathrm{m}$ of the soma. Pressure ejection of DHPG $(100 \mu \mathrm{M}, 80 \mathrm{~ms})$ from a patch pipette was performed using a Picospritzer II (Parker Hannifin Corporation, Cleveland, $\mathrm{OH}$ ). The puff pipette was placed on the surface of the slice $30-50 \mu \mathrm{m}$ from the cell body to minimize disturbance of the whole-cell patch by the pressure ejection artifact. The slices were pretreated with (5S,10R)-(+)-5-methyl-10,11-dihydro-5H-dibenzo[a,d]cyclohepten-5,10-imine (MK-801, 50-100 $\mu \mathrm{M})$ for at least $30 \mathrm{~min}$. Experiments were performed in the presence of 6,7-dinitroquinoxaline-2,3-dione $(10 \mu \mathrm{M}), \mathrm{MK}-801$ (100 nM), picrotoxin $(100 \mu \mathrm{M})$, CGP-55845 (100 nM), hexamethonium chloride $(50 \mu \mathrm{M})$, atropine $(100 \mathrm{nM})$, sulpiride $(200 \mathrm{nM})$, and MNI-137 (200 nM) to block AMPA, NMDA, GABAA, GABAB, nicotinic, M1 muscarinic, dopamine D2, and Group II mGluR receptors. Concentration-response experiments to DHPG were performed in the presence of apamin (200 nM) to block SK-mediated outward currents and to isolate mGluR-mediated inward currents. In some experiments, mGluR1 or mGluR5 receptors were blocked by bath perfusion of the negative allosteric modulators (NAMs) JNJ-16259685 (500 nM) or MPEP (300 nM), respectively.

\section{SK Channel Activity}

A voltage step protocol was used to analyze the SK conductance independent of mGluRs (Deignan et al, 2012). Briefly, the membrane potential was held at $-70 \mathrm{mV}$, stepped to $0 \mathrm{mV}$ for $50 \mathrm{~ms}$, and stepped back to $-50 \mathrm{mV}$ for $4 \mathrm{~s}$. The SK-mediated current was measured at $-50 \mathrm{mV}$ and isolated after subtraction of the current that remained after application of the selective SK-channel blocker apamin $(200 \mathrm{nM})$. Averages from five sweeps were analyzed.

\section{Drugs}

Cocaine was obtained from the National Institute on Drug Abuse Neuroscience Center (Bethesda, MD). CGP-55845, MNI-137, JNJ-16259685, MPEP, and VU-0357121 were obtained from Tocris (Minneapolis, MN). DHPG, CHPG, and apamin were obtained from Abcam (Cambridge, MA). The remaining compounds were obtained from SigmaAldrich (St Louis, MO).

\section{Data Analysis}

Activation of mGluRs causes both inward and outward currents resulting from Trp and SK channels, respectively. To determine the total charge transfer induced by mGluR activation, the area under the curve was measured for both currents, the absolute value of the inward component was added to the outward component for a complete representation of the size of the mGluR-induced response, and it was expressed as $\mathrm{pA}^{\star} \mathrm{S}$. For isolating the current induced by mGluR1 or mGluR5, selective receptor blockers were applied sequentially. Data are expressed as mean \pm SEM. Statistical 
significance was determined with Student's $t$-test or one-way ANOVA followed by the Tukey's post-hoc test. The difference was considered significant at $p<0.05$. When necessary, a two-way ANOVA was performed followed by Bonferroni's post hoc test. Data were graphed using Igor Pro 6 (Wavemetrics, Portland, OR) and analyzed using Prism 6 (GraphPad, La Jolla, CA). At least three biological replicates were tested per condition.

\section{RESULTS}

\section{A Single Injection of Cocaine Decreased mGluR-Induced Currents}

Activation of group I mGluRs on dopamine neurons can elicit both inward and outward currents (Figure 1). The inward current is owing to a Trp conductance (Tozzi et al, 2003), and the outward current is mediated by SK channels (Fiorillo and Williams, 1998). Both the inward and outward currents were blocked by the combination of the NAMs (referred to subsequently as blockers) JNJ $(500 \mathrm{nM}$ ) and MPEP (300 nM, Figure 2), which block mGluR1 and mGluR5, respectively. Mice were injected i.p. with saline or cocaine $(20 \mathrm{mg} / \mathrm{kg}) 24 \mathrm{~h}$ before recording, and the sensitivity to iontophoretically applied L-aspartate and bath application of DHPG were examined. Bath application of DHPG was used to construct concentration-response curves for the inward current after the blockage of SK with apamin $(200 \mathrm{nM})$. The rapid and local application of aspartate by iontophoresis was used to isolate the outward current. With these two methods, the inward and outward mGluR currents were examined independently in saline- and cocaine-injected animals.

In cocaine-treated animals, the trend of the inward current induced by DHPG applied over a wide range of concentrations was toward a smaller maximum response $(p=0.13)$. The only significant difference was at a near saturating concentration $(100 \mu \mathrm{M}$, Figure 1a; control: $143 \pm 30 \mathrm{pA}$; cocaine: $54 \pm 10 \mathrm{pA} ; \quad t(41)=3.72, \quad p<0.05, \quad$ Bonferroni's post-test). At higher concentrations, the inward current peaked and declined during that period of application (see Figure 1a for an example). Thus, accurate measurement of the peak current was blunted by the decline in the current, particularly at high concentrations during bath application of DHPG. The rapid decline in inward current prevented construction of an accurate concentration response curve in slices from both control and cocaine-treated animals. To avoid this problem, aspartate was applied by iontophoresis. This method resulted in reproducible outward currents that could be compared in slices from saline- and cocaine-treated animals (Figure 1b). The average peak outward current in slices from control animals was $78.2 \pm 16.2 \mathrm{pA}$, whereas the current in slices from cocaine-injected animals was significantly smaller $(32.9 \pm 5.3 \mathrm{pA}$, unpaired two-way $t$-test, $t(17)=3.01, p<0.05)$. These results indicate that after a single injection of cocaine there is a functional reduction in mGluRs signaling.

\section{SK is Unaffected in Slices From Cocaine-Treated Animals}

One explanation for a reduced outward current in slices from cocaine-injected animals is that the SK-mediated currents are
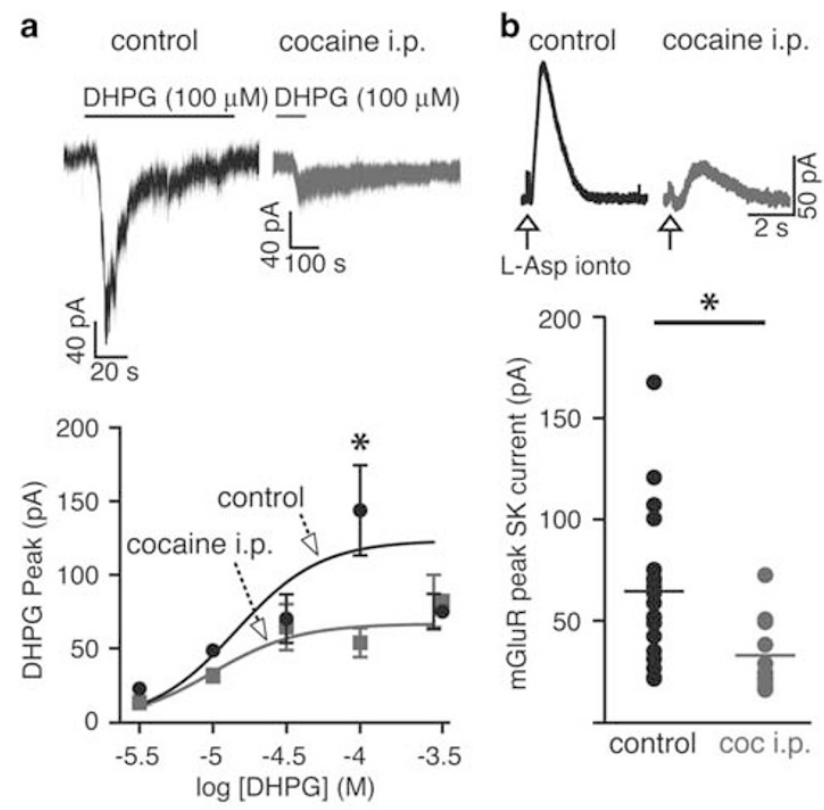

C

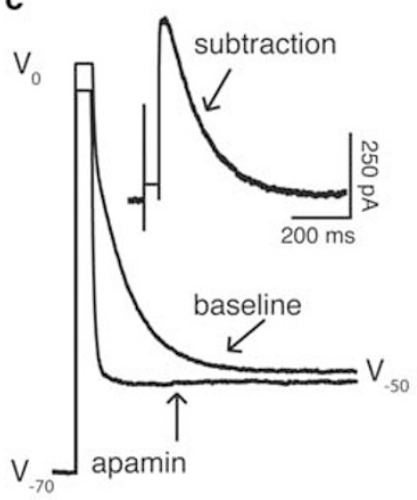

Figure I A single i.p. injection of cocaine decreased the maximum mGluR conductance. (a) A two-way ANOVA revealed no significant difference between the curves ( $n=3-10$ cells for each data point). When the current induced by DHPG $(100 \mu \mathrm{M})$ alone was tested, a post-hoc Bonferroni's test indicated a significant difference between saline- and cocaine-treated animals. (b) The outward current isolated using iontophoresis of L-aspartate indicated that the current was significantly decreased in slices from cocaine-treated animals (control $n=19$ cells; cocaine $n=||$ cells). The decrease in the mGluR outward current was not owing to a decrease in SK conductance. (c) The voltage step-induced SK current (see methods) before and after apamin (200 nM). Subtracted SK current (inset). (d) No significant difference between saline- and cocaine-injected animals (control $n=14$ cells; cocaine $n=12$ cells). (a) Each point represents a mean \pm SEM. Each point in (b) and (d) represents an individual cell, and bars indicate means; ${ }^{*} p<0.05$, ns, not significant.

reduced. The SK conductance evoked by a voltage step protocol was used to test this possibility. Using a step depolarization to evoke calcium entry followed by the return to $-50 \mathrm{mV}$, an apamin-sensitive (SK) current was identified (Figure 1c). The SK current in control animals $(107 \pm 12$ $\left.\mathrm{pA}^{\star} \mathrm{S}\right)$ was not significantly different from that in cocaineinjected animals $\left(89.7 \pm 9.5 \mathrm{pA}^{*} \mathrm{~S}, \quad t(24)=1.1, \quad p>0.05\right.$, unpaired $t$-test, Figure 1d). Thus, the reduction in the current induced by activation of mGluRs does not result from a decrease in channel expression, suggesting that the change is due to an altered receptor function. 

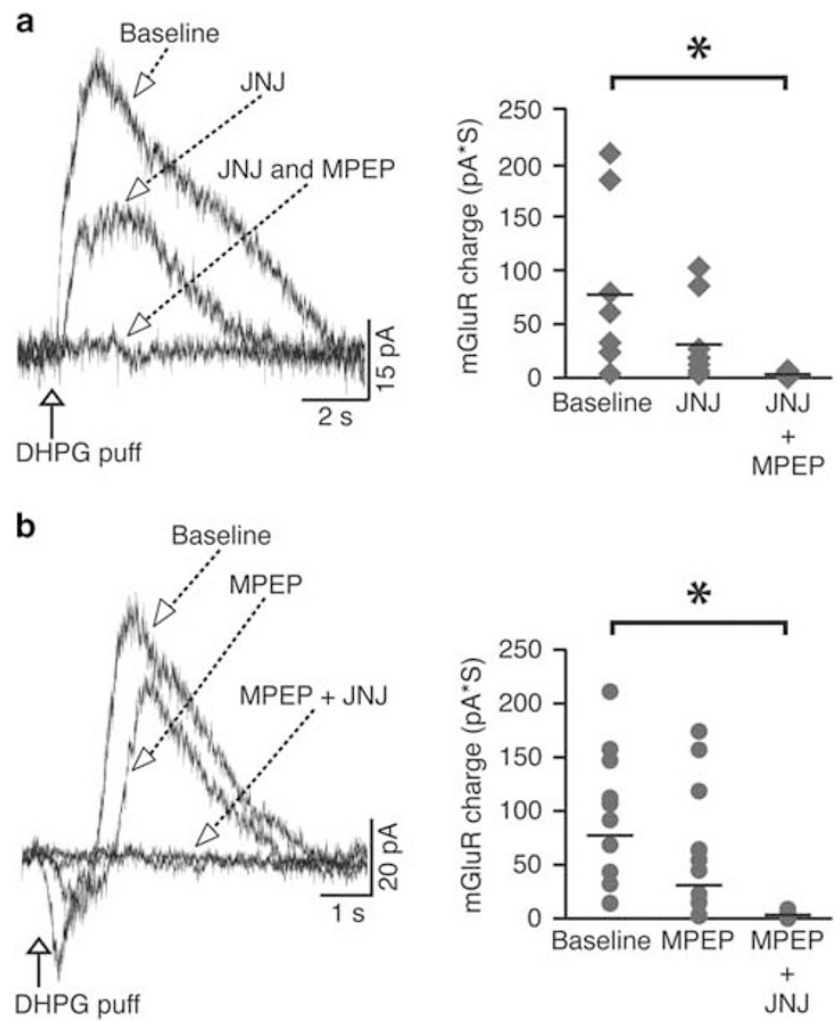

Figure $2 \mathrm{mGluRI}$ and mGluR5 contribute to DHPG-mediated currents. JNJ-I $6259685(500 \mathrm{nM})$ is an mGluRI-specific blocker, and MPEP (300 nM) is an mGluR5-specific blocker. The mGluR current was evoked by local puff application of DHPG (I00 $\mu \mathrm{M}, 80 \mathrm{~ms})$, and the area under the curve was measured. (a) JNJ is applied first and the average current is partially decreased, and then MPEP is applied and the average response is totally inhibited ( $n=9$ cells per condition). (b) MPEP is applied first and the average current is partially decreased, and then $\mathrm{JNJ}$ is applied and the average response is totally inhibited ( $n=12$ cells per condition). Each data point represents an individual cell, within subjects design across drug trials. $* p<0.05$, bars indicate means.

\section{SNc Dopamine Neurons Express both mGluR1 and mGluR5}

In these experiments, the mGluRs were activated using pressure ejection of DHPG $(100 \mu \mathrm{M})$. This method of agonist application resulted in a combination of inward and outward currents that were reproducible with repeated applications. Selective blockade of DHPG-induced currents using the mGluR1 blocker, JNJ (500 nM), or the mGluR5 blocker, MPEP (300 nM), was examined using successive application of each blocker on individual cells. The order of blocker application was alternated between cells. In these experiments, neither blocker alone completely eliminated the DHPG-induced currents. In general, each blocker inhibited about $50 \%$ of the current, and only after both blockers were applied was the current completely inhibited (JNJ first: baseline $77 \pm 24 \mathrm{pA}^{\star} \mathrm{S}$, JNJ and MPEP $1.89 \pm 0.62, q(8)=$ $4.45, p<0.05$, Figure 2a; MPEP first: baseline $92 \pm 18 \mathrm{pA}^{\star} \mathrm{S}$, MPEP and JNJ 2.56 $\pm 0.83, q(11)=7.30, p<0.05$, Figure $2 b$; post hoc Tukey's Test). The overall composition of the mGluR current varied between cells, with some cells expressing only mGluR1 (6/21), others with only mGluR5 (5/21), and most expressing both (10/21). a

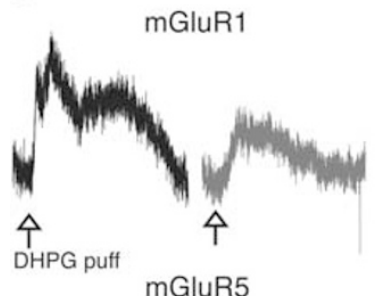

b

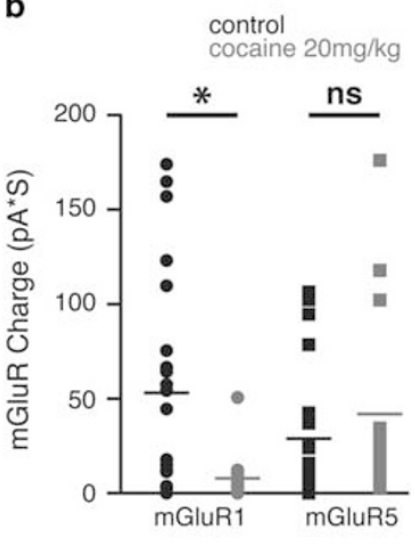

Figure 3 A single injection of cocaine significantly reduced mGluRI currents while leaving mGluR5 unaffected. DHPG-mediated pressure ejection currents were evoked from dopamine neurons and analyzed in control and cocaine-injected animals. (a) Example traces of isolated and subtracted mGluRI and mGluR5 DHPG-evoked currents from control and cocaine-injected animals. (b) Group data showing a significant decrease in mGluRI activity after a single injection of cocaine, with no significant change to mGluR5 (control $n=22$ cells; cocaine $n=14$ cells). $* p<0.05$, ns, not significant.

\section{Cocaine Treatment Selectively Decreased mGluR1 Currents}

Given that the mGluR current was reduced in slices from cocaine-treated animals, the next experiment determined which receptor subtype was involved. DHPG was applied by pressure application in slices taken from saline- and cocainetreated animals. As in previous experiments, following the acquisition of a stable mGluR current, MPEP $(300 \mathrm{nM})$ and JNJ $(500 \mathrm{nM})$ were successively applied to the slice. The average current activated in the presence of the first blocker was then subtracted from the initial current to establish the size of the current activated by the other mGluR group I subtype. The charge transfer evoked by mGluR5 in control animals was not significantly different from cocaine-treated animals (control $=28.9 \pm 7.6 \mathrm{pA}^{\star} \mathrm{S}$; cocaine-treated $=41.8 \pm$ $13.9 \mathrm{pA}^{\star} \mathrm{S} ; \quad t(68)=0.85, \quad p>0.05$ Bonferroni's post-test, Figure $3 \mathrm{~b}$ ). However, the mGluR1-induced current was significantly smaller in slices from cocaine-treated animals (control: $53.0 \pm 12.4 \mathrm{pA}^{\star}$; ; cocaine-treated: $7.8 \pm 3.5 \mathrm{pA}^{\star} \mathrm{S}$; $t(68)=2.97, p<0.05$, Bonferroni's post-test, Figure $3 b$ ). Therefore, a single injection of cocaine selectively reduced the size of the mGluR1 current while not affecting the size of the mGluR5 current.

\section{Acute Activation of mGluR5 Induces a Long-Lasting Depression of mGluR1-Induced Current}

In some neurons that express both mGluR1 and mGluR5, the activation of mGluR5 downregulates mGluR1 receptor function (Poisik et al, 2003). The current induced by activation of mGluR1 was examined before and after activation of mGluR5. Unlike the DHPG pressure ejection, iontophoretic application of aspartate most often induced an outward current that was primarily mediated by mGluR1s, as determined by the lack of inhibition of the peak current by 

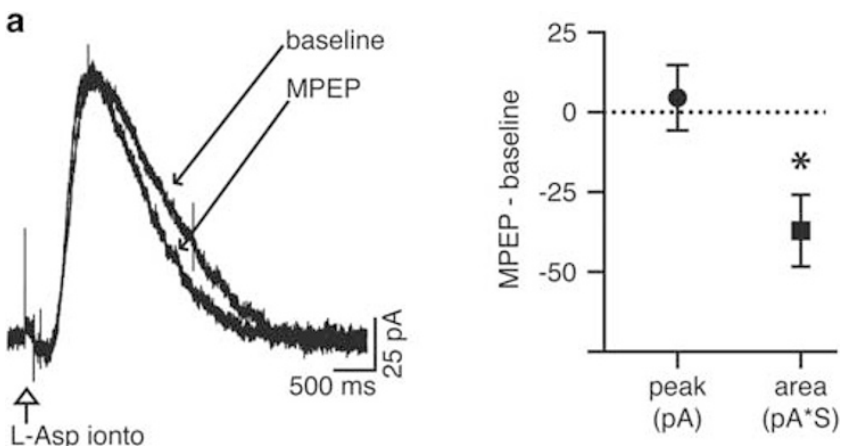

b
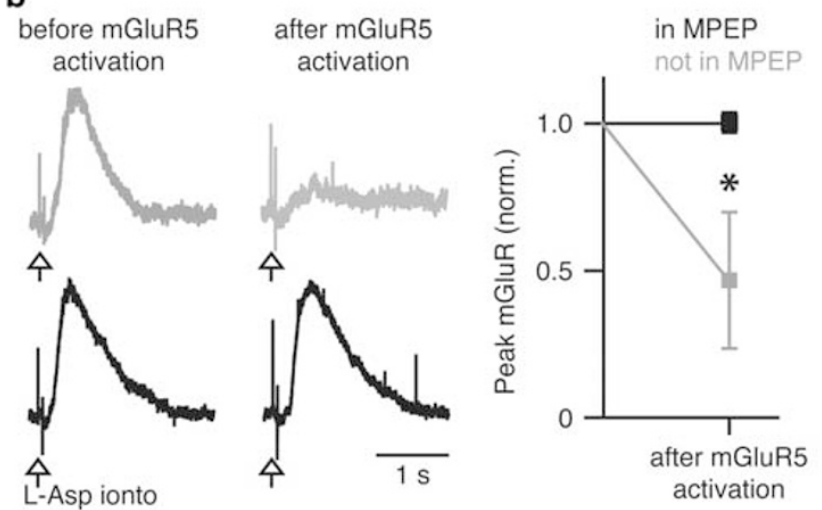

Figure 4 Acute activation of mGluR5 inhibits mGluRI currents. (a) MPEP had no effect on the peak current but significantly decreased the area of the aspartate-induced mGluR current. Left: an example trace showing the average baseline current and the average current after MPEP $(300 \mathrm{nM})$ in the same cell. Right: group data showing average MPEP_-baseline values for the peak current (in pA, $n=6$ cells) and the area under the curve (in pA*S, $n=6$ cells). (b) Left: example traces of mGluR current induced by iontophoresis before (left) and after (right) mGluR5 activation, in MPEP to block mGluR5 (black) and not in MPEP (gray). Right: group data showing the normalized effect on the peak of the mGluR iontophoretic-induced current after bath application of both CHPG $(50 \mu \mathrm{M})$ and VU-0357 I 2 I (500 nM) to selectively activate mGluR5 in the presence of MPEP ( $\mid \mu M, n=4$ cells) and the absence of MPEP ( $n=5$ cells). Traces are normalized to baseline. $* p<0.05$, markers and bars indicate means \pm SEM.

the mGluR5 selective blocker MPEP. The peak outward current induced by aspartate measured before and after the application of MPEP was not significantly different (difference is $+1.6 \pm 7.8 \mathrm{pA}, t(5)=0.45, p>0.05$, Figure $4 \mathrm{a}$ ). MPEP did, however, result in a significant decrease in the total charge transfer, indicating that there was a small contribution of outward current that was dependent on mGluR5s $(t(5)=3.29, \quad p<0.05$; two-tailed $t$-test, mean difference: $-37.1 \pm 11.3 \mathrm{pA}^{\star} \mathrm{S}$, Figure $4 \mathrm{a}$ ).

Selective activation of mGluR5 was achieved with the coapplication of the orthosteric agonist CHPG $(50 \mu \mathrm{M})$ and a positive allosteric modulator VU-0357121 (500 nM, $15 \mathrm{~min}$ ). This combination of agonists did not consistently induce a change in the holding current. However, the outward current activated by iontophoretically applied aspartate was significantly reduced, and it did not recover following washout of the mGluR5 agonists (Figure 4b; normalized baseline-wash: $53.5 \pm 13.9 \%, t(14)=3.84, p<0.05$, two-way ANOVA followed by Bonferroni's test). The reduction in the aspartateinduced mGluR current was prevented by the mGluR5 a

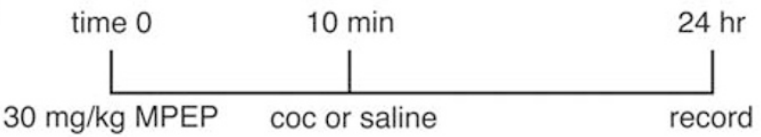

b

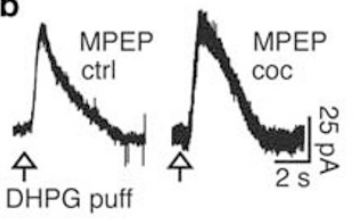

C

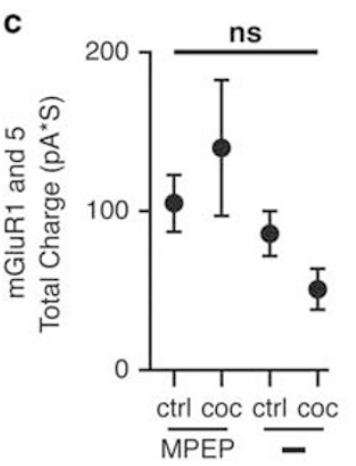

d

mGluR1

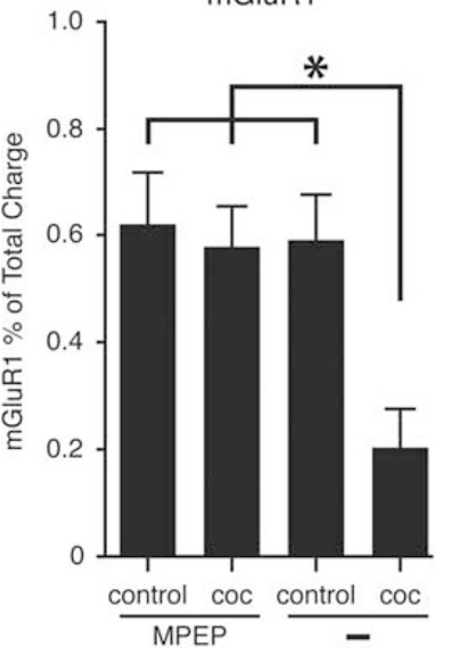

Figure 5 Blocking mGluR5 in vivo by i.p. injection of MPEP $(30 \mathrm{mg} / \mathrm{kg})$ prevented cocaine-induced inhibition of mGluRI current. (a) Schematic showing the protocol where animals were treated with MPEP followed by treatment with cocaine or saline. Experiments were performed $24 \mathrm{~h}$ later. (b) Example traces from MPEP+saline and MPEP+cocaine of DHPGevoked currents. (c) Group data showing no significant difference in the DHPG-induced mGluR current between MPEP+cocaine ( $n=14$ cells), MPEP+saline ( $n=12$ cells), control $(n=2 \mid$ cells), and cocaine $(n=15$ cells). (d) Group data comparing the percentage of the total mGluR charge transfer that is accounted for by mGluRI. There was a significant decrease of the mGluRI component only in mice treated with cocaine. There was no significant difference between the other three groups. ${ }^{*} p<0.05$; ns, not significant; markers and bars indicate means \pm SEM.

blocker MPEP $(1 \mu \mathrm{M})$, indicating that the activation of mGluR5 induced a long-term reduction of mGluR1dependent signaling.

\section{In Vivo Injection of MPEP Prevents Cocaine-Induced Decline in mGluR1 Signaling}

The next experiment examined whether the decrease in mGluR1 signaling induced by cocaine was dependent on the activation of mGluR5. Animals were treated with MPEP (30 mg/kg, i.p., (Gasparini et al, 1999)) $10 \mathrm{~min}$ before treatment with cocaine $(20 \mathrm{mg} / \mathrm{kg})$ or saline (Figure $5 \mathrm{a})$. There was no significant difference in the size of the mGluR charge transfer made up of both mGluR1 and mGluR5 induced by a pressure ejection of DHPG in any condition (MPEP+saline: $105 \pm 17.83 \mathrm{pA}^{\star} \mathrm{S} ; \mathrm{MPEP}+$ cocaine: $139.9 \pm$ $42.74 \mathrm{pA}^{\star} \mathrm{S}$; control: $85.9 \pm 14.2 \mathrm{pA}^{\star} \mathrm{S}$; cocaine: $50.98 \pm 12.8$ $\mathrm{pA}^{\star \mathrm{S}} ; \mathrm{F}(3,58)=1.75, p>0.05$; all post hoc comparisons were not significant at the 0.05 level using a Tukey's post hoc test, Figure 5c). Only when the mGluR1 component of the current in each cell was calculated as a fraction of the total mGluR baseline charge transfer from saline- and cocainetreated animals was it observed that a single injection of cocaine significantly reduced the mGluR1 component of the 
total (control $=59.1 \pm 8.5 \%$, cocaine $=20.4 \pm 7.2 \%, q(58)=4.88$, $p<0.05 ; \mathrm{MPEP}+$ saline $=62.0 \pm 9.7 \%, q(58)=4.58, p<0.05$; and $\mathrm{MPEP}+$ cocaine $=57.8 \pm 7.5 \%, \quad q(58)=4.30, \quad p<0.05$, Figure $5 \mathrm{~d}$ ). There was no significant change in the size of the fractional mGluR1 charge transfer between the MPEP + saline and saline conditions $(q(58)=0.35 p>0.05)$, indicating that pretreatment with MPEP did not alter the fraction of the total mGluR currents made up by either receptor.

These results revealed that blocking mGluR5 in vivo prevented the cocaine-induced decrease of the mGluR1 component of the overall mGluR current in midbrain dopamine neurons.

\section{DISCUSSION}

This study demonstrates the activation of currents made up by a combination of mGluR1- and mGluR5-dependent signaling in substantia nigra dopamine neurons. A single administration of cocaine selectively reduced mGluR1dependent currents without changing the current induced by activation of mGluR5. The acute activation of mGluR5 in brain slices reduced the mGluR1-dependent current. Blockade of mGluR 5 before administration of cocaine blocked the cocaine-induced decline in the mGluR1-dependent current. Thus, treatment with cocaine results in the activation of mGluR5 that functionally downregulates mGluR1.

The canonical reward pathway involves VTA neurons that project to the nucleus accumbens, and most literature that has examined changes in dopamine neurons in the VTA. There is, however, a growing body of literature implicating the substantia nigra dopamine neurons in the rewarding aspects of cocaine (Ilango et al, 2014; Ramayya et al, 2014; Rossi et al, 2013; Wise, 2009). This study suggests that plasticity of dopamine neurons in the substantia nigra can contribute at a cellular level to cocaine-induced modulation. There is, however, a significant difference in expression of SK between neurons in the substantia nigra and VTA (Wolfart et al, 2001). Dopamine neurons found in the substantia nigra have substantially greater currents mediated by SK than neurons in the VTA, particularly medial aspects of the VTA. Thus, the inward current induced by activation of mGluR1 dominates in the VTA, suggesting a qualitative difference between cells in the substantia nigra and VTA.

\section{Presence of mGluR5}

Previous studies in slices from rats found that mGluRinduced currents were not sensitive to mGluR5 blockers (Cui et al, 2007; Guatteo et al, 1999; Morikawa et al, 2003). However, dopamine neurons in the rat express transcript and protein for both mGluR1 and mGluR5 isoforms (Hubert et al, 2001; Testa et al, 1994). Technical differences between the way previous work and the present results were obtained most likely account for different results. In the present study, as was found previously, the peak outward current induced by iontophoretically applied aspartate was not reduced by blocking mGluR5 with MPEP. Although the peak current was not sensitive to MPEP, the total charge transfer was reduced, indicating a subtle action of mGluR5 activation. Pressure application of DHPG used in the present study also most likely resulted in a more widespread and prolonged activation of receptors compared with local iontophoretic application of aspartate that is a transporter substrate.

\section{Cocaine and mGluRs}

Enhancing mGluR1 activity by a positive allosteric modulator reverses cocaine-induced plasticity in dopamine neurons (Bellone and Luscher, 2006) and in medium spiny neurons of the nucleus accumbens (McCutcheon et al, 2011). In addition, in medium spiny neurons, negative allosteric modulation of mGluR1s leads to an increase of cocaineinduced cellular plasticity (Bellone and Luscher, 2006; Loweth et al, 2013). In multiple behavioral studies, negative modulation of mGluR5 decreased the behavioral effects of cocaine, decreasing cocaine self-administration, cocaine seeking, and cue-induced reinstatement (Keck et al, 2013, 2014; Kumaresan et al, 2009; Platt et al, 2008). This study provides a link between these behavioral studies and cellular studies by showing that negatively modulating mGluR5 in vivo can prevent a cocaine-induced decrease in mGluR1 signaling. This decrease in mGluR1 currents could result from internalization of receptors or a long-lasting desensitized state induced by the acute activation of mGluR $5 \mathrm{~s}$ after cocaine treatment. A number of mechanisms could be involved, including direct phosphorylation of the receptor. Phosphorylation of mGluR1 following the activation of mGluR5 by a PKC-dependent mechanism has been reported (Poisik et al, 2003). Regardless of the precise mechanism responsible for mGluR5 coordinating the decrease in mGluR1 signaling, these results reveal a novel and immediate consequence of cocaine treatment on dopamine neuron cellular physiology.

\section{FUNDING AND DISCLOSURE}

No competing financial interest. Support from NIH DA04523 and the OHSU Brain Institute Neurobiology of Disease Lacroute Fellowship. The authors declare no conflict of interest.

\section{ACKNOWLEDGMENTS}

This work was supported by NIH grant DA04523 (JTW) and the OHSU Brain Institute Neurobiology of Disease Lacroute Fellowship. We thank members of the Williams lab for their comments on the work and manuscript.

\section{REFERENCES}

Bellone C, Luscher C (2005). mGluRs induce a long-term depression in the ventral tegmental area that involves a switch of the subunit composition of AMPA receptors. Eur J Neurosci 21: $1280-1288$.

Bellone C, Luscher C (2006). Cocaine triggered AMPA receptor redistribution is reversed in vivo by $\mathrm{mGluR}$-dependent long-term depression. Nat Neurosci 9: 636-641.

Bird MK, Lohmann P, West B, Brown RM, Kirchhoff J, Raymond CR et al (2014). The mGlu5 receptor regulates extinction of cocainedriven behaviours. Drug Alcohol Depend 137: 83-89.

Chiamulera C, Epping-Jordan MP, Zocchi A, Marcon C, Cottiny C, Tacconi $S$ et al (2001). Reinforcing and locomotor stimulant effects of cocaine are absent in mGluR 5 null mutant mice. Nature Neuroscience 4: 873-874. 
Cui G, Bernier BE, Harnett MT, Morikawa H (2007). Differential regulation of action potential- and metabotropic glutamate receptor-induced $\mathrm{Ca} 2+$ signals by inositol 1,4,5-trisphosphate in dopaminergic neurons. J Neurosci 27: 4776-4785.

Deignan J, Lujan R, Bond C, Riegel A, Watanabe M, Williams JT et al (2012). SK2 and SK3 expression differentially affect firing frequency and precision in dopamine neurons. Neuroscience 217: 67-76.

Fiorillo CD, Williams JT (1998). Glutamate mediates an inhibitory postsynaptic potential in dopamine neurons. Nature 394: 78-82.

Gantz SC, Bunzow JR, Williams JT (2013). Spontaneous inhibitory synaptic currents mediated by a g protein-coupled receptor. Neuron 78: 807-812.

Gasparini F, Lingenhöhl K, Stoehr N, Flor PJ, Heinrich M, Vranesic I et al (1999). 2-Methyl-6-(phenylethynyl)-pyridine (MPEP), a potent, selective and systemically active mGlu5 receptor antagonist. Neuropharmacology 38: 1493-1503.

Guatteo E, Mercuri NB, Bernardi G, Knöpfel T (1999). Group I metabotropic glutamate receptors mediate an inward current in rat substantia nigra dopamine neurons that is independent from calcium mobilization. J Neurophysiol 82: 1974-1981.

Hermans E, Challiss RA (2001). Structural, signalling and regulatory properties of the group I metabotropic glutamate receptors: prototypic family C G-protein-coupled receptors. Biochem J 359: 465-484.

Hubert GW, Paquet M, Smith Y (2001). Differential subcellular localization of mGluR1a and mGluR5 in the rat and monkey Substantia nigra. J Neurosci 21: 1838-1847.

Ilango A, Kesner AJ, Keller KL, Stuber GD, Bonci A, Ikemoto S (2014). Similar roles of substantia nigra and ventral tegmental dopamine neurons in reward and aversion. J Neurosci 34: 817-822.

Jian K, Cifelli P, Pignatelli A, Frigato E, Belluzzi O (2010). Metabotropic glutamate receptors 1 and 5 differentially regulate bulbar dopaminergic cell function. Brain Res 1354: 47-63.

Keck TM, Yang H-J, Bi G-H, Huang Y, Zhang H-Y, Srivastava R et al (2013). Fenobam sulfate inhibits cocaine-taking and cocaineseeking behavior in rats: implications for addiction treatment in humans. Psychopharmacology 229: 253-265.

Keck TM, Zou M-F, Bi G-H, Zhang H-Y, Wang X-F, Yang H-J et al (2014). A novel mGluR5 antagonist, MFZ 10-7, inhibits cocainetaking and cocaine-seeking behavior in rats. Addict Biol 19: 195-209.

Kenny PJ, Boutrel B, Gasparini F, Koob GF, Markou A (2005). Metabotropic glutamate 5 receptor blockade may attenuate cocaine self-administration by decreasing brain reward function in rats. Psychopharmacology 179: 247-254.

Kumaresan V, Yuan M, Yee J, Famous KR, Anderson SM, Schmidt HD et al (2009). Metabotropic glutamate receptor 5 (mGluR5) antagonists attenuate cocaine priming- and cue-induced reinstatement of cocaine seeking. Behav Brain Res 202: 238-244.
Loweth JA, Scheyer AF, Milovanovic M, LaCrosse AL, Flores-Barrera E, Werner CT et al (2013). Synaptic depression via mGluR1 positive allosteric modulation suppresses cueinduced cocaine craving. Nat Neurosci 1-10.

Mannaioni G, Marino MJ, Valenti O, Traynelis SF, Conn PJ (2001). Metabotropic glutamate receptors 1 and 5 differentially regulate CA1 pyramidal cell function. J Neurosci 21: 5925-5934.

McCutcheon JE, Loweth JA, Ford KA, Marinelli M, Wolf ME, Tseng KY (2011). Group I mGluR activation reverses cocaineinduced accumulation of calcium-permeable AMPA receptors in nucleus accumbens synapses via a protein kinase C-dependent mechanism. J Neurosci 31: 14536-14541.

Morikawa H, Khodakhah K, Williams JT (2003). Two intracellular pathways mediate metabotropic glutamate receptorinduced $\mathrm{Ca} 2+$ mobilization in dopamine neurons. JNeurosci 23: 149-157.

Platt DM, Rowlett JK, Spealman RD (2008). Attenuation of cocaine self-administration in squirrel monkeys following repeated administration of the mGluR5 antagonist MPEP: comparison with dizocilpine. Psychopharmacology 200: 167-176.

Poisik OV, Mannaioni G, Traynelis S, Smith Y, Conn PJ (2003). Distinct functional roles of the metabotropic glutamate receptors 1 and 5 in the rat globus pallidus. Journal of Neuroscience 23: $122-130$.

Ramayya AG, Misra A, Baltuch GH, Kahana MJ (2014). Microstimulation of the human substantia nigra alters reinforcement learning. J Neurosci 34: 6887-6895.

Rossi MA, Sukharnikova T, Hayrapetyan VY, Yang L, Yin $\mathrm{HH}$ (2013). Operant self-stimulation of dopamine neurons in the substantia nigra. PLoS One 8: e65799.

Testa CM, Standaert DG, Young AB, Penney JB (1994). Metabotropic glutamate receptor mRNA expression in the basal ganglia of the rat. J Neurosci 14: 3005-3018.

Tozzi A, Bengtson CP, Longone P, Carignani C, Fusco FR, Bernardi G et al (2003). Involvement of transient receptor potential-like channels in responses to mGluR-I activation in midbrain dopamine neurons. Eur J Neurosci 18: 2133-2145.

Ungless MA, Whistler JL, Malenka RC, Bonci A (2001). Single cocaine exposure in vivo induces long-term potentiation in dopamine neurons. Nature 411: 583-587.

Wise RA (2009). Roles for nigrostriatal-not just mesocorticolimbic-dopamine in reward and addiction. Trends Neurosci 32: 517-524.

Wolfart J, Neuhoff H, Franz O, Roeper J (2001). Differential expression of the small-conductance, calcium-activated potassium channel SK3 is critical for pacemaker control in dopaminergic midbrain neurons. J Neurosci 21: 3443-3456.

Yu F, Zhong P, Liu X, Sun D, Gao H-Q, Liu Q-S (2013). Metabotropic glutamate receptor I (mGluR1) antagonism impairs cocaine-induced conditioned place preference via inhibition of protein synthesis. Neuropsychopharmacology 38: 1308-1321. 